\title{
Potential of surplus crop residues, horticultural waste and animal excreta as a nutrient source in the central and western regions of India
}

\author{
Sudeshna Bhattacharjya*, Asha Sahu, M. C. Manna and A. K. Patra \\ ICAR-Indian Institute of Soil Science, Nabibagh, Berasia Road, Bhopal 462 038, India
}

\begin{abstract}
In the recent past, yield stagnation in major cropping systems of India along with declined soil fertility and soil health have emerged as a prime threat to sustainable food security. Moreover, with the rising population, there is increase in food demand from the limited land resources. This situation has led to a huge gap between the availability of nutrients and demands to sustain food security. It has thus become the need of the hour to recover and recycle nutrients that have been mined from the soil. Hence, recycling of surplus crop and horticultural residues, and animal excreta seems to be a viable option to minimize the nutrient gap. However, cumulative estimated data on the availability of unutilized crop and horticultural residues, and animal excreta are scare in Indian context. The present article gives an estimate of recyclable biowaste in the states of central and western India, that could be utilized as baseline information by future policymakers.
\end{abstract}

Keywords: Animal excreta, crop residue, horticultural waste, waste.

A material is considered waste, unless it is recycled or converted into a value-added product. The rapid growth in human population, the consumption pattern of humans, subsequent urbanization, industrialization and agricultural intensification have resulted in the generation of an enormous quantity of urban and rural waste. Crop residues have been referred to as 'wastes', but they are also considered to be 'potential black gold' - a natural and valuable resource ${ }^{1}$, as they provide significant quantities of nutrients for crop production. Organic waste generated by agriculture, commercial and industrial activities is often disposed to the soils. The biodegradable waste available in India such as crop residues (from cereals, legumes, pulses, oilseeds, sugarcane, cotton, etc.), animal waste (from cow, buffalo, goat, sheep, poultry, etc.), agroindustrial waste, and city garbage have $\mathrm{C} / \mathrm{N}$ ratio ranging from 80 to 110 and low concentration of available plant nutrients, particularly $\mathrm{N}, \mathrm{P}$ and $\mathrm{K}$. On the basis of crop production levels, it is estimated that 10 major crops

\footnotetext{
*For correspondence. (e-mail: sudeshna.bb@outlook.com)
}

(rice, wheat, sorghum, pearl millet, barley, finger millet, sugarcane, potato tubers, pulses and oil seeds) of India generate approximately about 679.32-686 million tonnes (mt) of crop residue ${ }^{2}$, of which $226 \mathrm{mt}$ is actually available that has nutrient potential of about $5.6 \mathrm{mt}$ of nitrogen, phosphorus and potassium (NPK). The availability of all animal excreta is about $369 \mathrm{mt}$, of which $101 \mathrm{mt}$ is actually available that can potentially supply $3.474 \mathrm{mt}$ of $\mathrm{NPK}^{3}$. Per capita waste generation rate in India was $0.34 \mathrm{~kg} \mathrm{day}{ }^{-1}$ in 2012 , and is estimated to reach up to $0.71 \mathrm{~kg} \mathrm{day}{ }^{-1}$ in 2025 (ref. 4). In a recent survey, it has been estimated that about $64.8 \mathrm{mt}$ of city waste is generated every year from different cities of India that has nutrient potential of about $0.285 \mathrm{mt}$ of NPK. It is further estimated that $1 \mathrm{mt}$ increase in food-grain production will produce $1.2-1.5 \mathrm{mt}$ of crop residues, and one million increase in cattle population will provide an additional $1.2 \mathrm{mt}$ of dry dung per annum. Thus, the estimated NPK supply from all the waste, including crop residues is 5.0, 6.25 and $9.25 \mathrm{mt}$ respectively during the year 1991, 2011 and 2025 (ref. 5).

In spite of its huge nutrient potential, waste is being disposed regularly without being recycled. Most of the crop residues are burnt in northern and some parts of central India, and only one-third of the residues is being utilized for cattle manure. Similarly, two-thirds of animal waste are being used as fuel cake and the remaining onethird for manure production. However, under ordinary storage conditions, there is loss of plant nutrients either due to use as fuel cake, or by leaching or volatilization when the manure remains exposed to sun and rain. These scenarios thus highlight the significance of composting in a scientific manner to bring back the much needed organic and mineral components to the soil.

Apart from this, the present-day agriculture is facing major challenges like yield stagnation in crop production, declined fertilizer response ratio, secondary and micronutrient deficiency, and deterioration of soil quality. At the present level of crop production, annually there exists a negative balance of $10 \mathrm{mt}$ between the nutrient (NPK) removal by crops from soil and addition through fertilizers. The stagnation in fertilizer consumption and higher negative nutrient balance are posing a threat to soil health and sustainable agriculture ${ }^{6}$. Fertilizer consumption in 
REVIEW ARTICLES

Table 1. Generation, surplus and burning of crop residues $\left(\mathrm{CR}, \mathrm{mt} \mathrm{year}^{-1}\right)$ in the states of central and western India

\begin{tabular}{lcccc}
\hline States & Residue generation $^{\mathrm{a}}$ & Residue surplus $^{\mathrm{b}}$ & Residue burned $^{\mathrm{c}}$ & Residue burned $^{\mathrm{d}}$ \\
\hline Chhattisgarh & 10.49 & 3.50 & 1.84 & 0.83 \\
Goa & 0.26 & 0.09 & 0.08 & 0.04 \\
Gujarat & 71.65 & 23.88 & 6.69 & 3.81 \\
Madhya Pradesh & 46.52 & 15.51 & 3.46 & 1.91 \\
Maharashtra & 175.81 & 58.60 & 6.27 & 7.41 \\
Rajasthan & 38.11 & 12.70 & 3.58 & 1.78 \\
India & 342.82 & 114.27 & 21.92 & 15.78 \\
\hline
\end{tabular}

Source: ${ }^{\mathrm{a}}$ Ref. $14 ;{ }^{\mathrm{b}}$ Anon. ${ }^{25}$; ${ }^{\mathrm{b}}$ Bhardwaj ${ }^{26}$; ${ }^{\mathrm{c}}$ Based on IPCC coefficients; ${ }^{\mathrm{d}}$ Pathak et al. ${ }^{24}$.

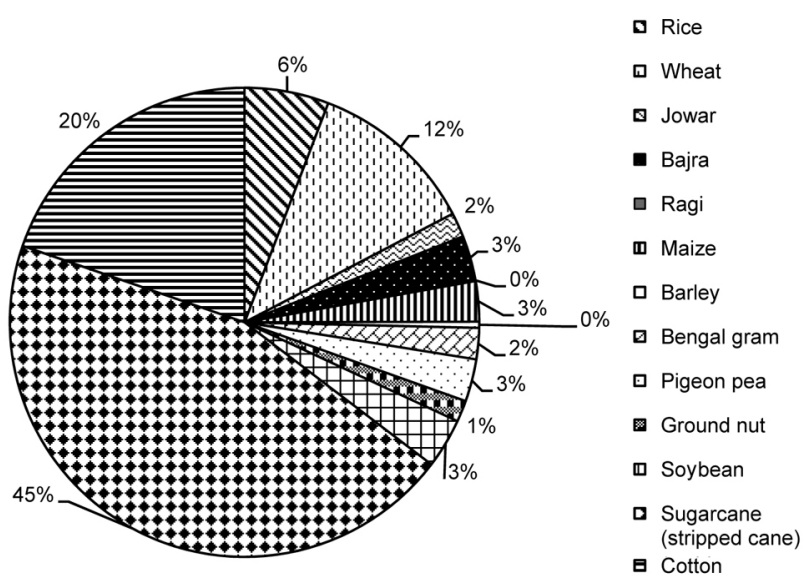

Figure 1. Per cent contribution of different crops in residue production and surplus residue generated in central and western India. Source: Ref. 14; Anon. ${ }^{25}$ and Bhardwaj ${ }^{26}$.

India is generally tilted more towards $\mathrm{N}$ followed by $\mathrm{P}$ and $\mathrm{K}$, mainly due to intensive crop production as well as government subsidy. In many areas in the country, imbalanced fertilization is the root cause of poor crop yield ${ }^{7}$. The negative yield trends were observed under long-term imbalanced N and NP fertilizer application in rice-wheatjute, soybean-wheat and sorghum-wheat systems in inceptisol, alfisol and vertisol respectively ${ }^{8}$. Continuous application of imbalanced NPK fertilizers alone minimized the crop yield and soil quality parameters. It was observed that the decline in yield was more pronounced with a concomitant decrease in soil organic carbon (SOC) content under imbalanced fertilizer application. Longterm application of NPK and NPK + FYM (farmyard manure) helped maintain or improve SOC content ${ }^{9,10}$. Therefore, to maintain soil organic matter (SOM) as well as to supplement nutrient requirement for crop production, recycling of crop residues, horticultural wastes and animal excreta is of utmost importance. Keeping in view the above facts, we have reviewed the availability of waste generated in the form of crop residues, horticultural waste and animal excreta in the state of central and western India, i.e. Madhya Pradesh (MP), Chhattisgarh, Rajasthan, Gujarat, Maharashtra and Goa, and further computed the surplus, their nutrient potential and feasible recycling options to achieve sustainable crop production, soil health and economy.

\section{Availability of crop residues}

In central and western India, approximately $342.82 \mathrm{mt}$ of crop residues is produced every year (Table 1). Among different crops, sugarcane generates the highest amount of $(154 \mathrm{mt})$ residues, followed by cereals $(87 \mathrm{mt})$, cotton (67 mt), chickpea and pigeon pea (17.4 mt each) and soybean and groundnut (16.8 $\mathrm{mt}$ each). Irrespective of crops, the highest amount of residues are generated from Maharashtra followed by Gujarat and MP. Furthermore, Maharashtra stands first in terms of sugarcane residue $(130.10 \mathrm{mt})$, whereas MP is dominant in pulse and oil seed crop residues (5.61 and $6.66 \mathrm{mt}$ respectively). Rajasthan ranks first in cereal residue generation, which is closely followed by MP. Figure 1 shows per cent contribution of different crops in residue generation.

\section{Availability of vegetable and fruit waste}

In central and western India, approximately $61.63 \mathrm{mt}$ of vegetable and fruit waste is produced every year (Table 2; data period 2010-11). The highest amount of vegetable and fruit waste is being generated in Maharashtra, followed by Gujarat. Tomato, potato, onion, brinjal, okra, cabbage and cauliflower are the main contributors of vegetable waste, whereas mango, banana, citrus, guava, papaya, sapota, grapes and pomegranate are the major contributors of fruit waste. Maharashtra produces the highest amount of tomato and onion waste; however, Gujarat ranks first in potato, brinjal, cabbage, cauliflower and okra waste production. Similarly, regarding fruit waste, the highest amount of mango waste $(1.09 \mathrm{mt})$ is produced by Gujarat, whereas Maharashtra dominates in banana, citrus, papaya, guava, pomegranate, sapota and grapes waste production. Figures 2 and 3 show per cent contribution of different vegetables and fruits in residue generation respectively.

The states of central and western India cumulatively produce $135.86 \mathrm{mt}$ of animal excreta (Table 3), of which 
Table 2. Generation, and surplus of vegetable and fruit waste (mt year ${ }^{-1}$ ) in the states of central and western India

\begin{tabular}{|c|c|c|c|c|}
\hline \multirow[b]{2}{*}{ State } & \multicolumn{2}{|c|}{ Vegetable } & \multicolumn{2}{|c|}{ Fruit } \\
\hline & Waste generation ${ }^{\mathrm{a}}$ & Waste surplus ${ }^{\mathrm{b}}$ & Waste generation $^{\mathrm{a}}$ & Waste surplus ${ }^{\mathrm{b}}$ \\
\hline Chhattisgarh & 3.14 & 1.57 & 0.90 & 0.45 \\
\hline Goa & 0.00 & 0.00 & 0.04 & 0.02 \\
\hline Gujarat & 9.05 & 4.53 & 7.98 & 3.99 \\
\hline Madhya Pradesh & 2.65 & 1.32 & 3.71 & 1.86 \\
\hline Maharashtra & 15.97 & 7.99 & 17.17 & 8.58 \\
\hline Rajasthan & 0.64 & 0.32 & 0.39 & 0.19 \\
\hline India & 31.45 & 15.73 & 30.18 & 15.09 \\
\hline
\end{tabular}

Source: ${ }^{\mathrm{a}, \mathrm{b}}$ Modified from Anon. ${ }^{25}$; Manna et $a .^{3}$ and ref. 27 (data period 2010-11).

Table 3. Contribution of different animals in total excreta production $(\mathrm{mt})$ in the states of central and western India

\begin{tabular}{lcc}
\hline Livestock & $\begin{array}{c}\text { Excreta } \\
\text { production }(\mathrm{mt})\end{array}$ & Percentage \\
\hline Cattle & 75.03 & 55.23 \\
Buffalo & 52.02 & 38.29 \\
Sheep & 2.08 & 1.53 \\
Goat & 5.81 & 4.27 \\
Pig & 0.30 & 0.22 \\
Horse and pony & 0.06 & 0.04 \\
Mule and donkey & 0.09 & 0.07 \\
Camel & 0.29 & 0.21 \\
Poultry (backyard + farm + hatcheries) & 0.19 & 0.14 \\
Total & 135.86 & \\
\hline
\end{tabular}

Source: Ref. 28.

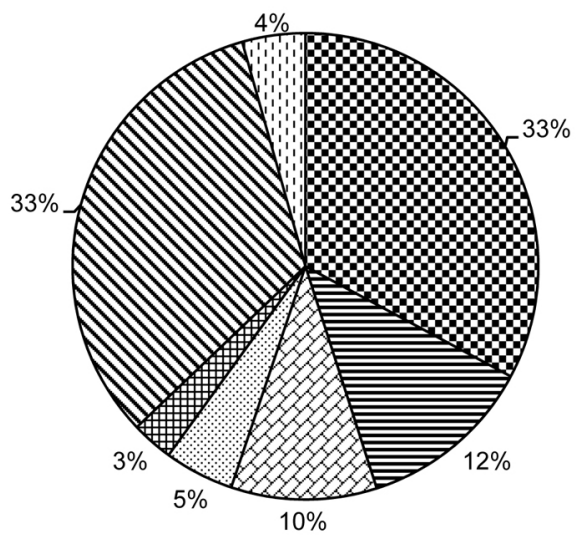

๑) Tomato

日 Potato

๑ Brinjal

․ Cabbage

田 Cauliflower

จ Onion

๑ Okra

Figure 2. Per cent contribution of different vegetables in waste production and surplus waste generated in central and western India. Modified from Anon. ${ }^{25}$; Manna et al. ${ }^{3}$ and ref. 27 (data period 2010-11).

the major portion is contributed by cattle, followed by buffalo and goat. The highest quantity of animal excreta is being generated by Rajasthan, followed by MP. The highest amount of cattle excreta is produced by MP, whereas the highest amount of buffalo and pig excreta is produced by Chhattisgarh. Rajasthan ranks first in goat

and sheep excreta production, whereas Maharashtra contributes the largest quantity of poultry excreta. Figure 4 shows per cent contribution of different states in animal excreta production.

\section{Surplus of crop residues}

In the states of central and western India, approximately $114.27 \mathrm{mt}$ (Table 1) crop residues remains surplus after different uses such as cattle feed, domestic fuel, bedding material for animals, etc (Table 1). Maharashtra produces the highest amount of surplus residues $(58.60 \mathrm{mt})$, followed by Gujarat $(23.88 \mathrm{mt})$. The major portion of total surplus residue is contributed by sugarcane. This is followed by total cereals (28.99 mt), cotton $(22.54 \mathrm{mt})$, bengal gram, pigeon pea $(5.79 \mathrm{mt}$ cumulative), soybean and groundnut (5.60 mt, cumulative not each).

Figure 1 shows per cent contribution of different crops in the generation of surplus residue.

\section{Surplus of vegetable and fruit waste}

In addition to crop residues, approximately $15.73 \mathrm{mt}$ vegetable waste and $15.03 \mathrm{mt}$ fruit waste are available as surplus for recycling (Table 2). Maharashtra dominates in both vegetable $(7.99 \mathrm{mt})$ and fruit $(8.58 \mathrm{mt})$ waste surplus compared to the other states in central and western India. Gujarat ranks second with respect to vegetable and fruit waste surplus for recycling. Figures 2 and 3 show per cent contribution of different vegetables and fruits in the generation of surplus waste respectively.

\section{Nutrient potential of crop residues and their recycling}

Crop residues are a potential source of plant nutrients and their beneficial effects on soil fertility and productivity can be harnessed by recycling them into the soil (Table 
Table 4. Nutrient potential of different crop residues in India

\begin{tabular}{lccccc}
\hline Crop & $\mathrm{N}(\%)$ & $\mathrm{P}_{2} \mathrm{O}_{5}(\%)$ & $\mathrm{K}_{2} \mathrm{O}(\%)$ & Total & t nutrients t $^{-1}$ residue \\
\hline Rice & 0.61 & 0.18 & 1.38 & 2.17 & 0.0217 \\
Wheat & 0.48 & 0.16 & 1.18 & 1.82 & 0.0182 \\
Sorghum & 0.52 & 0.23 & 1.34 & 2.09 & 0.0209 \\
Maize & 0.52 & 0.18 & 1.35 & 2.05 & 0.0205 \\
Pearl millet & 0.45 & 0.16 & 1.14 & 1.75 & 0.0175 \\
Barley & 0.52 & 0.18 & 1.30 & 2.00 & 0.0200 \\
Finger millet & 1.00 & 0.20 & 1.00 & 2.20 & 0.0220 \\
Pulses & 1.29 & 0.36 & 1.64 & 3.29 & 0.0329 \\
Oilseeds & 0.80 & 0.21 & 0.93 & 1.94 & 0.0194 \\
Groundnut & 1.60 & 0.23 & 1.37 & 3.20 & 0.0320 \\
Sugarcane & 0.40 & 0.18 & 1.28 & 1.86 & 0.0186 \\
Potato tuber & 0.52 & 0.21 & 1.06 & 1.79 & 0.0179 \\
\hline
\end{tabular}

Source: Ref. 29, t, tonnes.

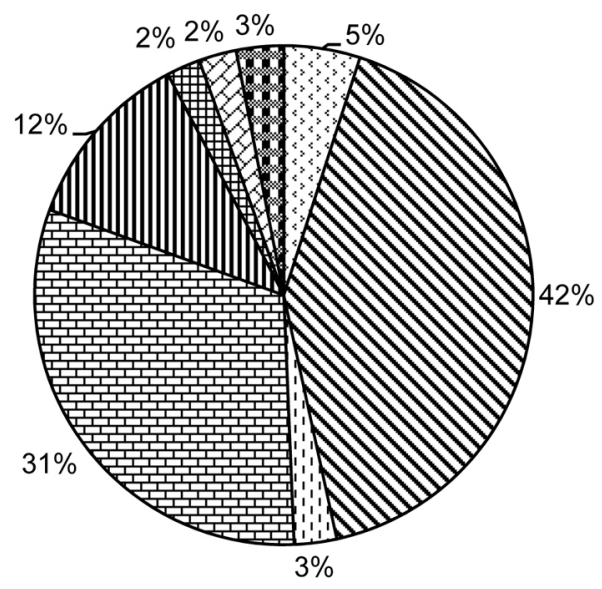

Figure 3. Per cent contribution of different fruits in waste production and surplus waste generated in central and western India. Modified from Anon. ${ }^{25}$; Manna et al. ${ }^{3}$ and ref. 27 (data period 2010-11).

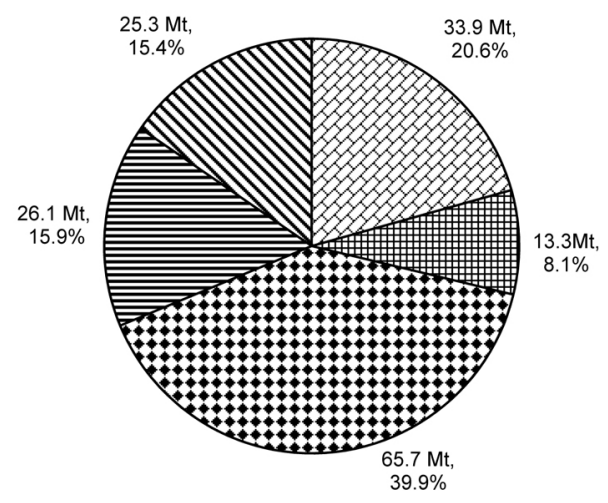

c Madhya Pradesh

B Chhattisgarh

D Rajasthan

B Gujrat

v Maharashtra

Figure 4. Total animal excreta produced in the western states India. Source: Ref. 28 and Jain and Kumar ${ }^{30}$.

4). Thus continuous removal and burning can lead to net loss of nutrients, which will ultimately lead to higher nutrient cost input in the short term and reduction in soil quality and productivity in the long term. Estimates show

that on an average $30-35 \%$ of applied $\mathrm{N}$ and $\mathrm{P}$ and 70 $80 \%$ of $\mathrm{K}$ accumulate in the crop residues of food crops. About $40 \%$ of $\mathrm{N}, 30-35 \%$ of $\mathrm{P}, 80-85 \%$ of $\mathrm{K}$, and 40 $50 \%$ of the $\mathrm{S}$ uptake by rice remains in the vegetative parts at maturity ${ }^{11}$. Similarly, about $25-30 \%$ of $\mathrm{N}$ and $\mathrm{P}$, $35-40 \%$ of $\mathrm{S}$, and $70-75 \%$ of $\mathrm{K}$ uptake is retained in wheat residue ${ }^{12}$. Moreover, crop residues are the primary source of organic matter (as $\mathrm{C}$ constitutes about $40 \%$ of the total dry biomass) ${ }^{13}$ which is indispensable for sustaining agricultural ecosystems. However, soil conditions, crop management, variety as well as season determine the nutrient concentration in crop residues.

In the states of central and western India, total nutrient potential (cumulative NPK content) of different surplus crop residues is $2.22 \mathrm{mt}$, surplus vegetable waste is $0.066 \mathrm{mt}$, surplus fruit waste is $0.068 \mathrm{mt}$ and surplus animal excreta is $3.90 \mathrm{mt}$ (Table 5). Among different states, Maharashtra has the highest cumulative nutrient potential from crop residues, horticultural waste as well as animal excreta.

The annual nutrient cycling in the plant-soil ecosystem is essential for maintaining a productive agricultural system. The crop residue management has important implications for the total amount of nutrients removed from and returned to the soil. The dynamics and bio-availability of main plant nutrient elements are also improved by SOM. Moreover, the amount, diversity, and activity of soil fauna and microorganisms are directly related to SOM content and quality. Carbon compounds in the residue are the fuel or energy sources for soil microbes and fauna responsible for biological recycling of these inorganic plant nutrients. During microbial decomposition of crop residues, mineral nutrients are released into the immediate environment that may be utilized by living plants or organisms. Carbon-enriched crop biomass becomes the primary food source for soil microorganisms and fauna, and as a result 'nurtures' the nutrient cycling.

Furthermore, management practices such as fertilization and the amount of residue remaining after harvest 
Table 5. Nutrient budget (mt) in terms of total $\left(\mathrm{N}+\mathrm{P}_{2} \mathrm{O}_{5}+\mathrm{K}_{2} \mathrm{O}\right)$ of different types of waste in the states of central and western India

\begin{tabular}{|c|c|c|c|c|c|}
\hline State & Crop residues* & Vegetable waste* & Fruit waste* & Animal excreta* & Total $^{\$}$ \\
\hline Chhattisgarh & 0.08 & 0.001 & 0.002 & 0.39 & 0.48 \\
\hline Goa & 0.002 & 0.000 & 0.000 & 0.00 & 0.00 \\
\hline Gujarat & 0.44 & 0.019 & 0.019 & 0.76 & 1.24 \\
\hline Madhya Pradesh & 0.34 & 0.005 & 0.009 & 0.99 & 1.34 \\
\hline Maharashtra & 1.12 & 0.032 & 0.037 & 0.75 & 1.94 \\
\hline Rajasthan & 0.24 & 0.001 & 0.001 & 1.01 & 1.26 \\
\hline Total & 2.22 & 0.066 & 0.068 & 3.90 & \\
\hline
\end{tabular}

Source: Manna et al. ${ }^{3}$; ref. 14; Anon. ${ }^{25}$; Bhardwaj $^{26}$; ref. 27 (data period 2010-11); ref. 28 and Tandon ${ }^{29}$.

*Nutrient potential $=$ surplus crop residues/vegetable waste/fruit waste/animal excreta $(\mathrm{mt}) \times$ percentage of nutrient $\left(\mathrm{N} / \mathrm{P}_{2} \mathrm{O}_{5} / \mathrm{K}_{2} \mathrm{O}\right)$.

${ }^{\$}$ Cumulative nutrient potential of crop residues, vegetable waste, fruit waste and animal excreta in terms of $\mathrm{N}+\mathrm{P}_{2} \mathrm{O}_{5}+\mathrm{K}_{2} \mathrm{O}$.
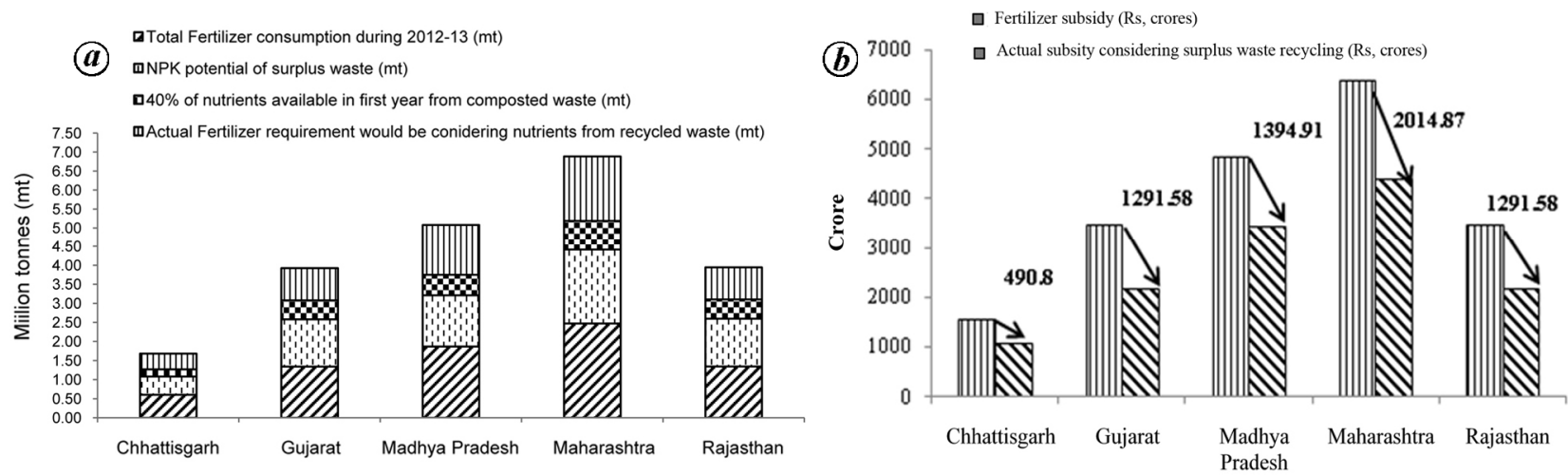

Figure 5. (a) Fertilizer consumption versus nutrient potential of surplus waste and (b) savings of fertilizer subsidy for the states of central and western India. Source: Ref. 14. *Calculation has been done taking into consideration the total fertilizer consumption in India during $2012-13$ of $25.54 \mathrm{mt}$ and total central subsidy on fertilizer during the same period of Rs 65,974 crores (subsidy on imported urea + indigenous urea + decontrolled $\mathrm{P}$ and $\mathrm{K}$ fertilizers). Black arrow along with the data (in crores) indicate the savings of subsidy on fertilizers.

determine the extent of cycling and plant availability of nutrients from crop residues. Henceforth, the shift from conventional to conservation tillage systems necessitates new research to determine the rate of cycling and plant nutrient availability.

\section{Fertilizer consumption versus nutrient potential of surplus waste}

Figure $5 a$ shows a comparative assessment between fertilizer consumption and the nutrient (NPK) potential of surplus wastes. The figure has been compiled from data derived from ref. 14 and Table 5. The highest fertilizer consumption as well as the highest NPK potential of surplus waste are found in Maharashtra, and the lowest in Chhattisgarh. Fertilizer consumption and the highest NPK potential of surplus waste of Goa are negligible compared to the other states, and thus, not considered here. The projection depicts a promising prospect as the surplus waste recycling can cumulatively contribute to reduction in fertilizer consumption of the states; still it is not enough to fulfil the nutrient demand for sustainable crop production. Even if the entire surplus waste is composted, it cannot meet the nutrient requirement for a single crop season, as only $30-40 \%$ of the composted nutrients are released during the first year of application. However, in economic terms recycling of surplus waste could save almost Rs 6483.74 crores government money that has been spent for fertilizer subsidy (Figure $5 b$ ).

\section{Management of waste (crop residues, vegetable and fruit waste, and animal excreta)}

\section{In-situ decomposition of crop residues}

Surface retention, incorporation (in situ) and composting (ex situ) are the promising on-farm management options to address the issue of burning as well as maintaining soil health and long-term sustainability of crop productivity. To achieve in situ decomposition, different technologies are available now. For example, in situ decomposition of rice and wheat residues where $4000 \mathrm{~kg}$ fresh cow dung 


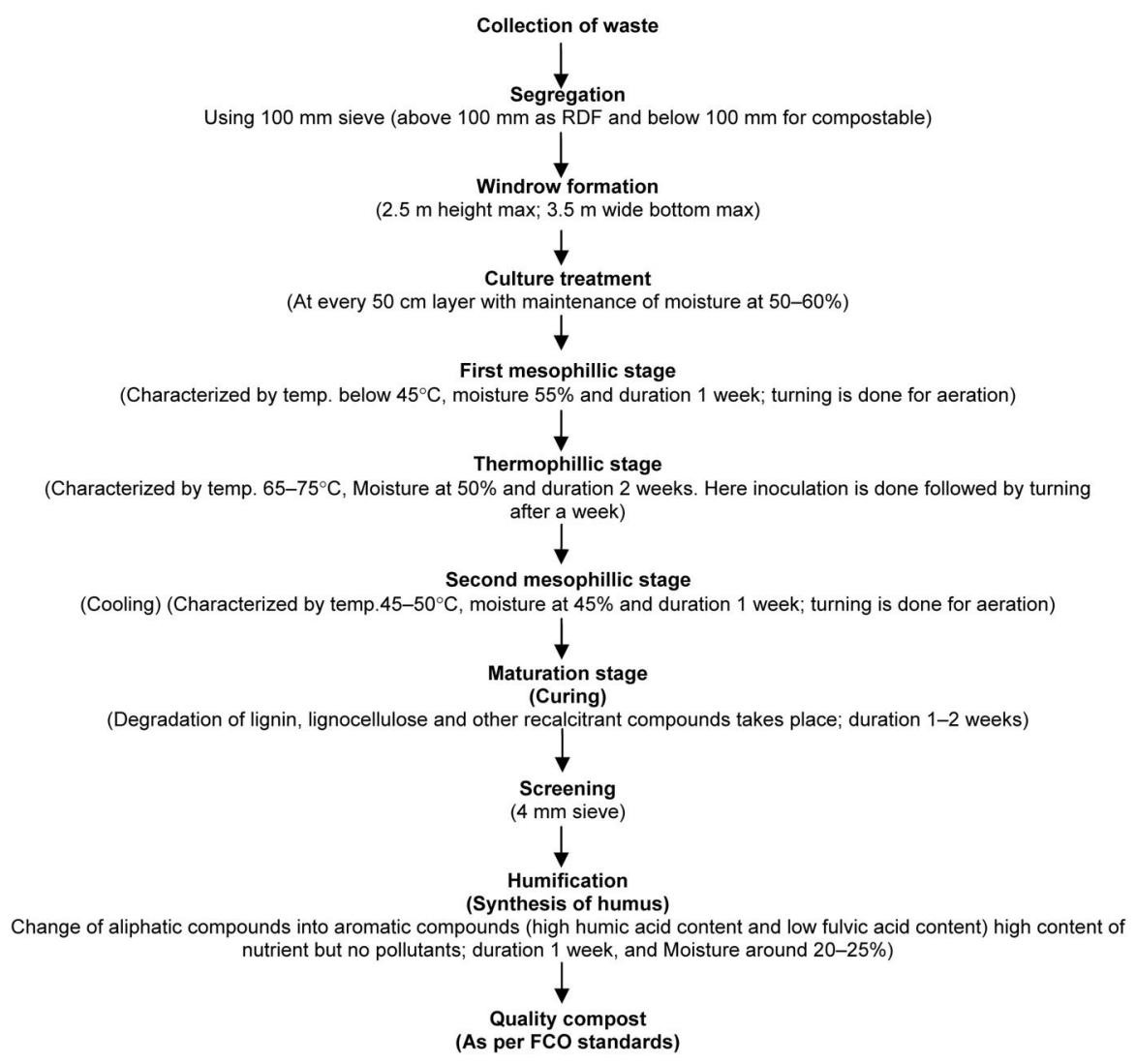

Figure 6. 'Seven stages of composting' for preparing good-quality compost.

slurry along with $37 \mathrm{~kg}$ urea, $50 \mathrm{~kg}$ molasses, $25 \mathrm{~kg}$ curd, $1.7 \mathrm{~kg}$ mycelial mat (cellulolytic fungi) and 34 litre of microbial inoculum (lingo-cellulolytic bacteria and actinomycetes) are added and spread over the residues. One irrigation is applied immediately after spreading the consortia followed by thorough mixing and incorporation into the soil by a tractor-drawn rotavator. The second irrigation is given after 15 days of incorporation and residue decomposition is complete after one month. The same technology has also been successfully used to decompose sugarcane trash with 45 days $^{15,24}$. Another technological innovation for in situ residue management is the latest version of the Turbo Happy Seeder ${ }^{16,17}$. A straw management system (SMS) known as Super-SMS has been developed and commercialized by Punjab Agricultural University, Ludhiana, to equip the combine harvesters with mechanized straw spreaders ${ }^{18,19}$. In this technology, SMS can be attached with all existing combines for paddy harvesting and spreading of straw uniformly in situ for facilitating the subsequent operation of Happy Seeder for the sowing of wheat crop, that is operated through a tractor.

\section{Ex situ composting}

The potential of composting to turn on-farm waste materials into a farm resource makes it an attractive proposi- tion. Composting is a microbiological, non-polluting and environmentally safe method for disposal and recycling of such waste by converting it into organic fertilizer.

Another important aspect of composting is the stability or maturity of the compost. The terms stability and maturity are often used interchangeably to describe the degree of decomposition and transformation of the organic matter in compost ${ }^{20}$. There are different physico-chemical indicators to validate compost stability and also rapid tests used at composting plants to track compost stabilization during the process. Loss of $\mathrm{CO}_{2}-\mathrm{C}$, content of $\mathrm{NH}_{4}-\mathrm{N}$ and $\mathrm{NO}_{3}-\mathrm{N}, \mathrm{pH}$, electrical conductivity and total humic substances (humic and fulvic acid) serve as the physico-chemical indicators of compost stability. The self-heating test on the undried, sieved samples is another stability test recommended ${ }^{21}$. The maximum temperature $\left(T_{\max }\right)$ reached is used to evaluate the rotting degree of the compost from degree I (fresh material, $T_{\max }>60^{\circ} \mathrm{C}$ ) to degree $\mathrm{V}$ (mature compost, $T_{\max }<30^{\circ} \mathrm{C}$ ). Composts are considered as finished when temperature does not exceed $40^{\circ} \mathrm{C}$ during the test (rotting degrees IV and V). For preparing good quality compost from waste, it is necessary for the organics to go through the 'seven stages of composting' (Figure 6).

The history of composting dates back to that of early agriculture; however, the contemporary composting initiated in India is with the innovation of Indore method 


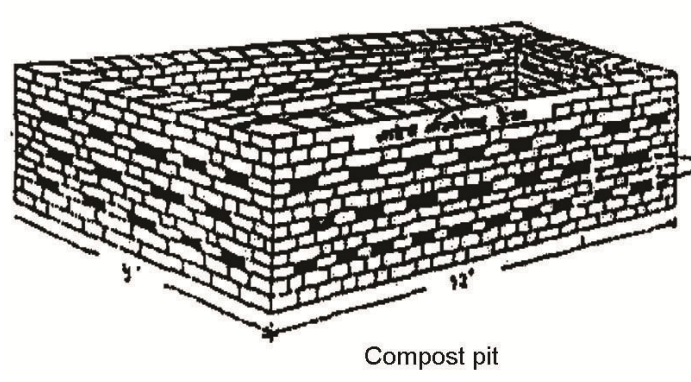

Compost pit

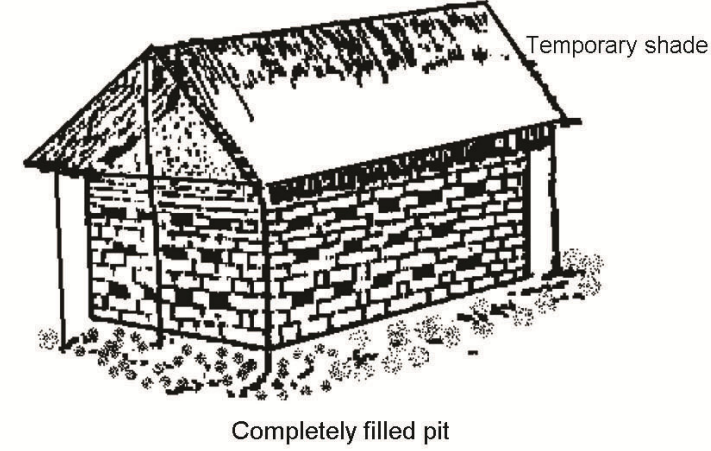

Completely filled pit

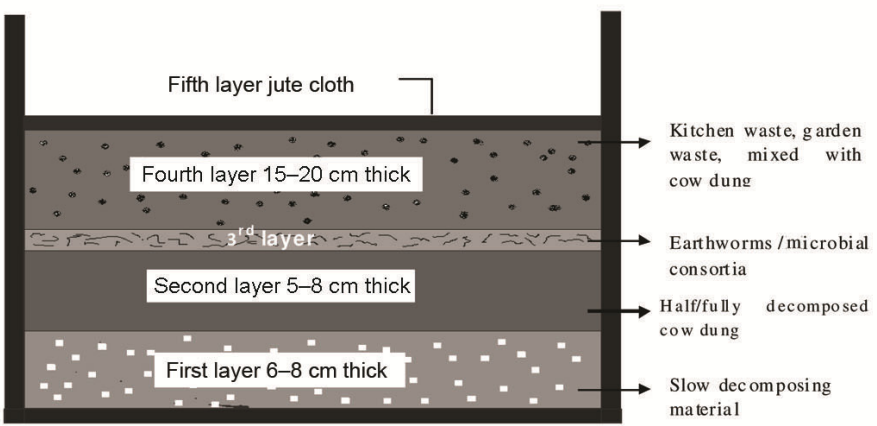

Diagrammatic representation of successive layers to be made for composting in pit

Figure 7. Illustration of a compost pit. Source: Manna et al. ${ }^{3}$.

of composting. The rural waste (farmyard waste, household waste, agricultural wastes, etc.) and city waste are usually composted following either pit/heap or trench method (Figure 7), which takes about 6-7 months to mature with 2-3 turnings at 15 days intervals. A range of methods, including traditional to modern, manual to mechanical, that are scientifically designed and tested are being used to produce good-quality compost, which represents a completely decomposed brown homogeneous humic product in about three months. The compost resembles the traditional FYM in appearance and properties. The average nutrient content of the compost prepared by this method is $0.5-0.8 \% \mathrm{~N}, 0.3-0.5 \% \mathrm{P}_{2} \mathrm{O}_{5}$ and $1-1.5 \% \mathrm{~K}_{2} \mathrm{O}$. Some scientific methods of composting along with their salient features are discussed below.

\section{Phospho-sulpho-nitro compost technology}

This method employs both fortification and acceleration strategy using rock phosphate, pyrites, micas, urea nitrogen and lignocellulolytic microbes so that the endproduct contains more nutrients per unit weight. For the production of a tonne of phosphor-sulpho-nitro $(\mathrm{P}-\mathrm{S}-\mathrm{N})$ compost (PSNC), waste (1000 kg), cow dung (200 kg), rock phosphate $(333 \mathrm{~kg})$, pyrites $(120 \mathrm{~kg})$, urea $(13 \mathrm{~kg})$ and soil $(50 \mathrm{~kg})$ are required. Mature PSNC after 110 days of decomposition contains approximately $3.2-4.2 \%$ $\mathrm{P}$ and $1.5-2.3 \% \mathrm{~N}$.

\section{Organo-mineral compost}

In this method, $\mathrm{P}, \mathrm{K}$ and $\mathrm{S}$-enriched compost is prepared by pit method using wheat straw, cattle dung, rock phosphate, waste mica and mineral gypsum. The compost obtained after four months of decomposition contains about $1 \% \mathrm{~N}, 1 \%$ total $\mathrm{P}, 2.1 \%$ total $\mathrm{K}$ and $1.7 \% \mathrm{~S}$. Moreover, it can substitute $24 \%$ of chemical fertilizers in terms of $\mathrm{P}$ requirement and would be more cost-effective to apply in soils prevalent in large parts of Rajasthan, and most of the Indo-Gangetic Plains having low available phosphorus and organic carbon.

\section{Microbial-enriched compost}

In this technique, a consortium of bioinoculum has been used to enhance the decomposition process to recycle city garbage by pit or windrow method, and the compost is ready for field application after 1.5-2 months. Fungal culture is added at $500 \mathrm{~g}$ mycelial mat per tonne of material. Initially, at 1-5 days, bioinoculum such as Aspergillus heteromorphus, Aspergillus terrus, Aspergillus flavus and Rhizomucor pusillus is added and owing to a high initial temperature $\left(55-70^{\circ} \mathrm{C}\right)$ at the thermophilic stage, the bioinoculum is again added after 30 days of decomposition. A microbial-enriched compost technology has, thus, been developed using cellulolytic organisms to accelerate the process of decomposition and to increase 
Table 6. Organic manure produced (mt) in the states of central and western India

\begin{tabular}{lcccc}
\hline State & Rural compost & Urban compost & FYM & Vermicompost \\
\hline Madhya Pradesh & 4.50 & 0.35 & 8.55 & 0.20 \\
Chhattisgarh & 8.03 & 0.32 & 3.60 & 0.20 \\
Rajasthan & 1.97 & 1.51 & 25.25 & 0.0036 \\
Gujarat & - & - & 35.80 & 0.05 \\
Maharashtra & - & - & - & 0.017 \\
Goa & 1.57 & 0.002 & - & 0.002 \\
\hline
\end{tabular}

Modified from ref. 14 .

the manurial value compared to the existing MSW compost.

\section{Vermicompost}

Vermicomposting is an effective method of converting waste into useful manure with the help of earthworms to recycle decomposable organic waste such as animal excreta, kitchen waste, farm residue, forest litter, etc. Epigeic earthworms are known to be used for vermicomposting. These include (i) Eisenia foetida, Eudrilus eugeniae, Perionyx excavatus and Decogester bolaui. The first two are exotic and the last two are indigenous to India. These species are most suited because these are prolific breeders with high multiplication rate, have short life cycles with less mortality and are voracious feeders which excrete high-quality vermicasts. They are easy to handle, have a lifespan of 1-1.5 years, are sturdy and survive well throughout the year under varying weather conditions. Such species are easily available and economically feasible for vermicomposting.

\section{Rapid compost}

Rapid composting is the need of the hour for reducing the time required for obtaining good quality compost. This technology is especially suitable for recycling of kitchen waste and vegetable waste. The uniqueness of this technology is to inoculate thermophilic lignocellulolytic microbes at the thermophilic stage of composting to accelerate decomposition rate and reduce the time-frame. For the preparation of $100 \mathrm{~kg}$ compost, $150 \mathrm{~kg}$ waste material, $50 \mathrm{~kg}$ fresh cow dung, $1.1 \mathrm{~kg}$ urea and consortia of fungi bacteria and actinomycetes are required. It would produce compost within 1-1.5 months.

\section{Status of composting}

Among different states of central and western India, the highest quantity of rural compost is produced in Chhattisgarh and urban compost in Rajasthan. However, huge quantity of FYM is being produced by Gujarat, followed by Rajasthan (Table 6). Case studies on the impact of
PSNC application on yield potential and fertilizer substitution showed that application of 10 tonnes PSNC can substitute $99-100 \%$ of recommended fertilizer dose in groundnut and green gram, whereas 5 tonnes of PSNC can replace $98 \%$ of recommended fertilizer dose in soybean (Table 7). Similarly, 10 tonnes vermicompost can substitute $100 \%$ of recommended fertilizer dose in pearl millet and 5 tonnes can replace $85 \%$ of recommended fertilizer dose in chickpea ${ }^{3}$.

\section{Challenges of waste recycling}

The success of waste recycling depends mainly upon four factors: technology availability, accessibility, affordability and technology diffusion. SWOT analysis revealed that most of the challenges of waste management concern the lack of suitable facilities such as equipment and infrastructure, underestimation of waste-generation rates, inadequate management and technical skills. In comparison to developed countries, the Indian scenario depicts that it is not actively involved in the recycling process, recycling plans and techniques ${ }^{22,23}$. Moreover, little involvement of private sector, inappropriate choice of methods for waste recycling, lack of holistic policy measures and inadequate incentives/subsidies have resulted in poor outcome ${ }^{23}$. The Ministry of Environment, Forest and Climate Change (MoEF), GoI/Pollution Control Boards/states do not have complete data about the various kinds of waste being generated in the country. Risks to health/environment have also not been adequately assessed by MoEF, GoI/states. Rare instances of the polluter being held responsible for unsafe disposal and absence of a single body taking ownership of waste issues in India have made recycling more difficult. Public attitude towards waste is also a major barrier to improving waste management in India.

In the agriculture sector, field burning of crop residues $(15.78-21.92 \mathrm{mt})^{24}$ is the greatest threat against recycling them into the field. Unavailability of labour, high cost in removing the residues, lack of requisite machinery to incorporate crop residues in soil, and use of combine harvesters in rice, wheat and sugarcane-based cropping systems have made the problem more stringent. 
REVIEW ARTICLES

Table 7. Comparative effectiveness of compost and recommended dose of fertilizers on crop productivity in different soils of India

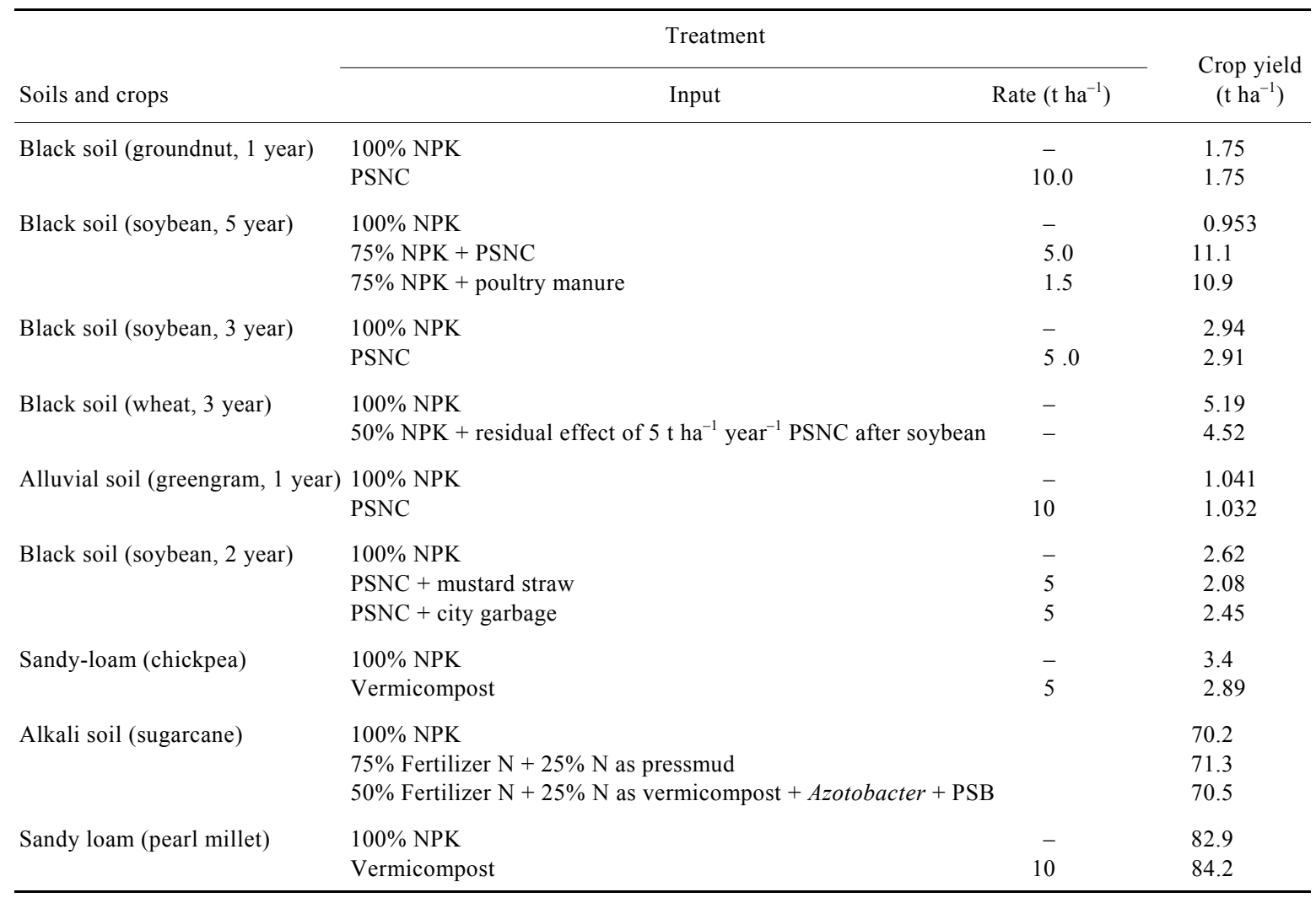

NPK, Recommended dose of fertilizer; PSNC, Phospho-sulpho-nitro-compost; PSB, P-solubilizing bacteria. Source: Manna et al. ${ }^{3}$.

\section{Scope of future research}

The Indian states are generating huge amounts of waste in terms of crop residues, horticultural waste and animal excreta. There is a trade-off between different competing uses of waste depending upon the need of the people. Lack of knowledge regarding management is causing loss of huge amounts of waste material and in turn resulting in environment pollution. Moreover, the lack of quantitative data base on the amount of waste generated, used and surplus in different states of India makes this problem more acute. Therefore, a study to generate a database of waste material at the national scale is of utmost importance for future research and policy development.

Waste recycling could play an instrumental role in integrated nutrient management for sustaining crop productivity. If recycling of waste really improves fertilizer use efficiency in the long term needs to be examined.

Composting is a beneficial way to recycle surplus waste; however, compost generated in India is of low quality. Thus fortification with externally added nutrients and microorganisms could enrich the low-grade compost for better utilization.

Though crop residues recycling is already recommended as an integrated part of conservation agriculture, farmers are facing a major challenge of slower decomposition of crop residues, which is leading to their burning in the Indo-Gangetic Plains. Thus, further pilot-scale research on in situ decomposition/management, as well as SOC enrichment, is the need of the hour.

1. Reicosky, D. C. and Wilts, A. R., Crop-residue management. In Reference Module in Earth Systems and Environmental Sciences Encyclopedia of Soils in the Environment, Elsevier, Amsterdam, Netherlands, 2005, pp. 334-338.

2. Hiloidhari, M., Das, D. and Baruah, D. C., Bioenergy potential from crop residue biomass in India. Renew. Sustain. Energ. Rev., 2014, 32, 504-512.

3. Manna, M. C., Subba Rao, A., Sahu, A. and Singh, U. B., Compost Handbook: Research-Production-Application, Fertilizer Development and Consultation Organization, New Delhi, 2012, pp. $132+$ xiii.

4. Manna, M. C. et al., Quality compost production from solid urban waste for enhancing crop productivity and soil health. Bulletin No. 02/IISS/2017, Indian Institute of Soil Science, Bhopal, 2017, pp. $1-63$.

5. Manna, M. C., Sahu, A., Patra, A. K., Khanna, S. S., Chaudhari, S. K. and Sikka, A. K., Rapid composting technique: ways to enhance soil organic carbon, productivity and soil health. In ICAR-Indian Institute of Soil Science Technology Folder, 2015, pp. $1-8$.

6. Subba Rao, A. and Reddy, K. S., Emerging strategies for sustaining higher productivity and ensuring soil quality under intensive agriculture. Fertilizer News, 2005, 1(4), 61-76.

7. Manna, M. C. et al., Long-term effect of fertilizer manure application on soil organic carbon storage, soil quality and yield sustainability 
under sub-humid and semi-aridtropical India. Field Crops Res. 2005, 93, 264-280.

8. Manna, M. C., Subba Rao, A. and Mandal, A., Maintenance of soil biological health under different crop production systems. Indian J. Soil Conserv., 2013, 41, 127-135.

9. Manna, M. C. et al., Soil organic matter in a West Bengal Inceptisol after 30 years of multiple cropping and fertilization. Soil Sci. Soc. Am. J., 2006, 70, 121-129.

10. Manna, M. C., Swarup, A., Wanjari, R. H., Mishra, B. and Shai, D. K., Long-term fertilizer, manure and liming effects on soil organic matter and crop yields. Soil Till. Res., 2007, 94, 397-409.

11. Dobermann, A. and Fairhurst, T. H., Rice straw management. Better Crops Int., 2002, 16, 7-9.

12. Singh, Y. and Sidhu, H. S., Management of cereal crop residues for sustainable rice-wheat production system in the Indo-Gangetic Plains of India. Proc Indian Natl. Sci. Acad., 2014, 80, 95-114.

13. Chatterjee, R., Gajjela, S. and Thirumdasu, R. K., Recycling of organic wastes for sustainable soil health and crop growth. Int. $J$. Waste Resour., 2017, 7, 296.

14. Fertiliser Statistics 2012-13, Fertilizer Association of India, New Delhi, 2013, 58th edn.

15. Patra, A. K., Manna, M. C., Sahu, A. and Bhattacharjya, S., In situ composting: a potential alternative to residue burning. In Souvenir of National Conference on Organic Waste Management for Food and Environmental Security, ICAR-Indian Institute of Soil Science, Bhopal, 8-10 February 2018, pp. 35-40.

16. Jat, M. L., Climate smart agriculture in intensive cereal based systems: scalable evidence from Indo-Gangetic Plains. In Agriculture under Climate Change-Threats, Strategies and Policies (eds Belavadi, V. V. et al.), Allied Publishers Pvt Ltd, 2017, pp. 147154.

17. Jat, M. L. et al., Assessing soil properties and nutrient availability under conservation agriculture practices in a reclaimed sodic soil in cereal-based systems of North-West India. Arch. Agron. Soil Sci., 2018, 64, 531-545.

18. Milham, N., Kumar, P., Crean, J. and Singh, R. P., Policy instruments to address air pollution issues in agriculture: implications for Happy Seeder technology adoption in India. Final Report, Australian Centre for International Agricultural Research (ACIAR), FR2014-17, 2014; aciar.gov.au/publication/fr2014-17.

19. Lohan, S. K. et al., Burning issues of paddy residue management in north-west states of India. Renew. Sustain. Energ. Rev., 2018, 81, 693-706.
20. Zomra-Nahum, S., Markovitch, O., Tarchitzky, J. and Chen, Y., Dissolved organic carbon (DOC) as a parameter of compost maturity. Soil Biol. Biochem., 2005, 37, 2109-2226.

21. FCQAO, Methods book for the Analysis of Compost. KompostInformation Nr. 230. BudesgutegemeinschaftKomposte. V. (English translation by W. Bidlingmaier, University of Essen, Germany), 1994.

22. Chatterjee, R., Municipal solid waste management in Kohima cityIndia. Iran. J. Environ. Health. Sci. Eng., 2010, 7, 173-180.

23. Manna, M. C. et al., Bio-waste management in subtropical soils of India: future challenges and opportunities in agriculture. $A d v$. Agron., 2018, 157, 87-148.

24. Pathak, H., Bhatia, A. and Jain, N., Inventory of greenhouse gas emission from agriculture. Report submitted to Ministry of Environment and Forests, GoI, 2010.

25. Anon., Agricultural Statistics at a Glance, Directorate of Economics and Statistics, Ministry of Agriculture, GoI, 2009; http// www.dacnet.nic.in/eandds

26. Bharadwaj, K. K. R., Recycling of crop residues, oilcakes and other plant products in agriculture. In Fertilizers, Organic Manures, Recycling Wastes and Bio-fertilizers (ed. Tandon, H. L. S.), Fertilizer Development and Consultation Organization, New Delhi, 1995, pp. 9-30.

27. Indian Horticultural database - 2013, National Horticulture Board, Ministry of Agriculture, Government of India, 2014.

28. 19th Livestock Census - 2012, All India Report, GoI, Ministry of Agriculture, Department of Animal Husbandry, Dairying and Fisheries, 2014.

29. Tandon, H. L. S., Organic resources: an assessment of potential supplies, their contribution to agricultural productivity and policy issues for Indian agriculture from 2000-2025. In Plant Nutrient Needs, Supply, Efficiency and Policy Issues, 2000-2025 (eds Kanwar, J. S. and Katyal, J. C.), National Academy of Agricultural Sciences, New Delhi, 1997, pp. 15-28.

30. Jain, M. C. and Kumar, S., Recycling of animal waste in agriculture. Recycling of crop, animal and industrial wastes in agriculture. In Fertilizers, Organic Manures, Recycling Wastes and Bio-Fertilizers (ed. Tandon, H. L. S.), Fertilizer Development and Consultation Organization, New Delhi, 1995, pp. 50-67.

Received 12 July 2018; revised accepted 25 January 2019

doi: $10.18520 / \mathrm{cs} / \mathrm{v} 116 / \mathrm{i} 8 / 1314-1323$ 